J. Clin. Chem. Clin. Biochem.

Vol. 27, 1989, pp. $781-786$

(C) 1989 Walter de Gruyter \& Co.

Berlin - New York

\title{
Biochemical Diagnosis of an Hereditary Aminolaevulinate Dehydratase Deficiency in a 63-Year-Old Man
}

\author{
By A. Hassoun, L. Verstraeten \\ Department of Clinical Biochemistry, Université Catholique de Louvain. Cliniques Universitaires St Luc, \\ Bruxelles, Belgique
}

R. Mercelis and J.-J. Martin

Department of Neurology, Universitaire Instelling Antwerpen, Universitair Ziekenhuis Antwerpen, Antwerpen, België

(Received April 5/June 30, 1989)

Summary: Porphyrin metabolism was investigated in a 63-year-old male patient who developed a subacute onset polyneuropathy with predominance of motor signs in the upper limb.

The screening for lead, cadmium, mercury, aluminium and thallium was negative. The study of porphyrin metabolism showed remarkable abnormalities, particularly a very high level of plasmatic 5-aminolaevulinic acid contrasting with a normal level of porphobilinogen and a nearly complete loss of activity of aminolaevulinic acid dehydratase with no regenerative response to dithiothreitol or zinc ions. The other causes of aminolaevulinic acid dehydratase deficiency (tyrosinaemia, alcoholism, smoking, cirrhosis, renal insufficiency, diabetes mellitus) were ruled out.

The diagnosis of primary aminolaevulinic acid dehydratase deficiency was proposed and confirmed by the familial study, which revealed the existence of several heterozygous members in this family.

\section{Introduction}

Hereditary aminolaevulinic acid dehydratase (porphobilinogen synthase) ${ }^{1}$ ) deficiency is a very rare cause of acute hepatic porphyria. Until now, to our knowledge, only three homożygous known cases have been reported $(1,2)$. Lead intoxication, which is a common phenomenon, also causes a loss of activity of aminolaevulinic acid dehydrätase, but it is reversible by dithiothreitol or zinc ions (3).

\footnotetext{
${ }^{1}$ Enzymes

Aminolaevulinate dehydratase $=$ porphobilinogen synthase (EC 4.2.1.24)

Porphobilinogen deaminase (EC 4:3.1.8)
}

To our knowledge, our patient had not suffered from any serious illness, even neurological or haematological. Then, at the age of 63 , he developed a subacute polyneuropathy for which he was hospitalized. The shoulder girdle muscles and the extensors of the wrist were severely affected, and the lower limb muscles were affected to a lesser degree. Sensory impairment was minimal. At the same time, early signs of myeloproliferative disease were found.

This study describes the contribution of biochemical investigations to the diagnosis of this rare type of porphyria. We also report the results of the investigation of the family for this enzyme defect. 


\section{Materials and Methods}

Plasma and urinary 5-aminolaevulinic acid and porphobilinogen were determined spectrophotometrically, after elution from ion-exchange resins (Bio-Rad, West Germany), according to the Mauzerall \& Granick method (4), adapted as follows for plasmatic determinations: $4 \mathrm{ml}$ of plasma are adjusted to $\mathrm{pH}$ 6.5 with acetic acid $1 \mathrm{~mol} / \mathrm{l}$ or $\mathrm{NaOH} 1 \mathrm{~mol} / \mathrm{l}$, then centrifuged. The usual procedure for urine is then followed. After ionexchange separation, the eluate must be filtered on a MillexSR $0.5 \mu \mathrm{m}$ filter (Millipore, France) before adding Ehrlich's reagent.

Urinary porphyrins: uroporphyrin fraction, coproporphyrin fraction and faecal porphyrins:coproporphyrin and protoporphyrin were determined spectrophotometrically after liquid extraction (5). Urinary and faecal porphyrins were separated by high performance liquid chromatography (HPLC) using a method derived from those of Ford et al. (6) and de Verneuil \& Nordmann (7). The chromatographic system consisted of a SP 8700 solvent delivery system (Spectra-Physics, U. S. A.), a KS Nucleosil 120-5 C $18(100 \mathrm{~mm})$ column (Macherey-Nagel, West Germany), a fluorimeter Fluoromat FS 950 (Kratos, U.S. A.) as detector (excitation: $400 \mathrm{~nm}$; emission: $600 \mathrm{~nm}$ ) and a single range recorder BD 7 (Intersmat, U. S. A.). The internal standard was mesoporphyrin IX dimethylester (Porphyrin products, U.S. A.).

Erythrocyte zinc protoporphyrin was measured with a haematofluorometèr (8).

For aminolaevulinate dehydratase (EC 4.2.1.24), the Berlin \& Schaller method was used (9). The enzyme was reactivated by addition of both $20 \mathrm{mmol} / 1$ dithiothreitol (10) and $0.1 \mathrm{mmol} / 1$ zinc chloride (11).

Erythrocyte porphobilinogen deaminase (EC 4.3.1.8) was determined fluorimetrically with a fluorimeter Fluoromat FS 950 (Kratos, U.S. A.) according to Deybach, C., Grandchamp, B. \& Nordmann, $Y$. (unpublished).

Blood and urine analyses for lead were determined according to Blanke \& Decker (12) with a graphite furnace atomic absorption spectrometer 2380 (Perkin Elmer, U. S. A.) and a HGA 400 oven (Perkin Elmer, U.S. A.).

Urine mercury was determined by atomic absorption spectrometry according to Coyle \& Hartley (13).

Urine cadmium and thallium were determined according to Kubasik \& Volosin (14) with an atomic absorption 4000 spectrometer (Perkin Elmer, U.S. A.) and a HGA 500 oven (Perkin Elmer, U.S. A.). Plasma aluminium was determined by atomic absorption spectrometry according to Valentin et al. (15).

Urine and serum amino acid analyses were performed by an ion-exchange chromatographic method, according to Bremer et al. (16), using a TMS 1 amino acid analyser (Technicon, U.S.A.). The ethylenediaminetetraacetate (EDTA) mobilization test for lead excretion was performed by i.v. administration of $1600 \mathrm{mg}$ of calcium EDTA in 30 minutes.

The red blood cell, white blood cell, platelet count, haematocrit, blood haemoglobin and white blood cell differentiation were performed with a H-1 Technicon analyzer (Technicon, USA).

Plasma glucose and creatinine were performed with a Hitachi 717 analyzer (Hitachi, Japan).

\section{Results}

The investigation was started with toxicological screening for heavy metals involved in toxic polyneuropathy. The urinary levels of lead, cadmium, mercury and thallium were within the normal ranges, as were plasma lead and aluminium and the results of the EDTA lead mobilization test (tab. 1).

However, the urinary screening for porphyrins indicated an increased excretion of these compounds (tab. 2).

i

Tab. 1. Heavy metal determination.

\begin{tabular}{lll}
\hline & Results & $\begin{array}{l}\text { Reference } \\
\text { values }\end{array}$ \\
\hline Blood Pb $(\mu \mathrm{mol} / \mathrm{l})$ & 0.34 & $<1.21$ \\
Urine Pb $(\mu \mathrm{mol} /$ day) & 0.05 & $<0.39$ \\
EDTA Pb test $(\mu \mathrm{mol} /$ day) & 0.07 & $<0.39$ \\
Plasma Al $(\mu \mathrm{mol} / \mathrm{l})$ & 0.33 & $<0.74$ \\
Urine Cd $(\mu \mathrm{mol} /$ day) & 0.01 & $<0.13$ \\
Urine $\mathrm{Hg}(\mu \mathrm{mol} / \mathrm{g}$ creatinine) & 0.02 & $<0.10$ \\
Urine Tl (nmol/1) & $\mathrm{N} . \mathrm{D}$. & $<10.0$ \\
\hline
\end{tabular}

EDTA: ethylenediaminetetraacetate

N. D.: not detected

Tab. 2. Porphyrin metabolism.

Results Reference values

Plasmatic precursors

5-Aminolaevulinate $(\mu \mathrm{mol} / \mathrm{l}): \quad 6.8 \quad 0-0.6$

Porphobilinogen $(\mu \mathrm{mol} / \mathrm{l})$

$0.0 \quad 0-0.2$

Urine porphyrins and precursors

5-Aminolaevulinate $(\mu \mathrm{mol} / \mathrm{l})$

Porphobilinogen $(\mu \mathrm{mol} / \mathrm{l})$

Uroporphyrin fraction (nmol/day)

Coproporphyrin fraction (nmol/day) $2333 \quad 0-230$

HPLC determination

Uroporphyrin (\%)

Heptacarboxyporphyrin (\%)

Hexacarboxyporphyrin (\%)

Pentacarboxyporphyrin (\%)

Coproporphyrin $(\%)$

$\begin{array}{rc}800 & 0-30 \\ 5 & 0-9 \\ 244 & 0-6 \\ 2333 & 0-230 \\ & 0-10 \\ 3 & 0-29 \\ 4 & 0-9 \\ 6 & 0-8 \\ 15 & 0=8\end{array}$

Faecal porphyrins

Coproporphyrin (nmol/g dry weight) $174 \quad 0-60$

Protoporphyrin (nmol/g dry weight) $187 \quad 0-60$

HPLC determination

Coproporphyrin (\%)

Protoporphyrin (\%)

$55 \quad 35-80$

\begin{tabular}{ccc} 
Protoporphyrin (\%) & 45 & $19-60$ \\
\hline Blood zinc protoporphyrin (nmol/g Hb) & 19 & 4
\end{tabular}

Erythrocyte porphobilinogen deaminase *

(uroporphyrin, $\mathrm{pmol} / \mathrm{h} \cdot \mathrm{mg} \mathrm{Hb}$ )

$665.103-243$

Erythrocyte aminolaevulinate dehydratase

(5-aminolaevulinate, $\mu \mathrm{mol} / \mathrm{min} \cdot 1$ ery-

throcytes)

without additions

after addition of $20 \mathrm{mmol} / \mathrm{l}$

dithiothreitol

after addition of $0.1 \mathrm{mmol} / \mathrm{l}$

zinc chloride

$\begin{array}{ll}0.3 & 20-60 \\ 0.6 & 20-60 \\ 0.4 & 20-60\end{array}$

Red blood cells $\left(10^{12} / 1\right)$

$4.9 \quad 4.0-6.1$

* Result obtained with two different samples.

$$
\text { : }
$$

J. Clin. Chem. Clin. Biochem. / Vol. 27, 1989 / No. 10 
A more complete study of porphyrins in urine, blood and faeces, and their precursors was performed. The results obtained (tab. 2), especially the significant increase of 5-aminolaevulinate in urine and plasma with porphobilinogen concentrations within normal limits, suggested a deficiency of aminolaevulinic acid dehydratase. The activity of aminolaevulinic acid dehydratase was therefore determined in erythrocytes, in the presence and in the absence of both dithiothreitol and zinc ions as reactivators. We also determined the activity of porphobilinogen deaminase ${ }^{1}$ ) in erythrocytes. The results obtained are presented in table 2. Tyrosinaemia was ruled out as a possible cause of aminolaevulinic acid dehydratase deficiency, because the levels of plasma tyrosine $(55 \mu \mathrm{mol} / \mathrm{l})$ were within normal. limits $(50-76 \mu \mathrm{mol} / 1)$, and urine tyrosine $(81 \mu \mathrm{mol} / \mathrm{g}$ creatinine; reference values: $30-$ $220 \mu \mathrm{mol} / \mathrm{g}$ creatinine) was also normal. Four relatives were also studied: one sister, one brother, the daughter and the grand-daughter of the patient. The results are presented in table 3.

On admission, the erythrocyte count was $4.9 \times 10^{12} / 1$ (reference values: $4.0-6.1 \times 10^{12} / 1$ ), the haematocrit was 0.44 (reference values: $0.37-0.52$ ) and haemoglobin was $152 \mathrm{~g} / 1$ (reference values: $120-180 \mathrm{~g} / \mathrm{l}$ ). The white blood cell count was $11.9 \times 10^{9} / 1$ (reference values: $\left.4.0-10.8 \times 10^{9} / 1\right)$ with a 0.85 granulocyte fraction. The platelet count was $768 \times 10^{9} / 1$ (reference values: $\left.150-450 \times 10^{9} / 1\right)$. Bone marrow biopsy revealed a local increase in the number of megacaryocytes. This case was first described as an incipient myeloproliferative disorder and it was not treated. A year later, the following haematological values were found: erythrocyte count: $7.27 \times 10^{12} / 1$, haemoglobin: $171 \mathrm{~g} / 1$, haematocrit: 0.55 , leukocyte count: 9.8 $\times 10^{9} / 1$ and platelet count: $661 \times 10^{9} / 1$. On cytolog ical and histological examination, the patient's bone marrow was hypercellular and had an increased number of megacaryocytes with occasional hypersegmentation of the nuclei. There was a slight loss of granulation of the granulocytes and a relative eosinophilia. The red cell line was hyperplastic. According to these results, the patient was considered to have a myeloproliferative disease of primary polycythaemia type.

Plasma glucose was $5.5 \mathrm{mmol} / 1$ (reference values: $3.9-5.8 \mathrm{mmol} / \mathrm{l}$ ) and plasma creatinine was $88 \mu \mathrm{mol} / \mathrm{l}$ (reference values: $35-132 \mu \mathrm{mol} / \mathrm{l})$. After oral loading with $100 \mathrm{~g}$ of glucose, plasma glucose was $10.8 \mathrm{mmol} / \mathrm{l}$ after 2 hours, and $8.8 \mathrm{mmol} / \mathrm{l}$ after 3 hours.

\section{Discussion}

The activity of aminolaevulinic acid dehydratase is most frequently reduced by a heavy metal intoxication, commonly lead, but it is also decreased in various conditions: chronic ethylism $(17,18)$, cirrhosis (19), smoking $(20,21)$, renal insufficiency (22) and diabetes mellitus (23). All these causes were ruled out in our patient by anamnestic, clinical and biochemical investigations. However, the oral glucose tolerance test was abnormal, but the plasma glucose levels remained always between normal limits during the hospitalization of the patient.

Heavy metals other than lead, i.e. aluminium (24), mercury (25) and cadmium (26), do not decrease the activity of aminolaevulinic acid dehydratase in concentrations that are toxic in vivo. In vitro, very much higher concentrations of these metals can cause an inhibition $(24,27)$.

A rare cause of aminolaevulinic acid dehydratase inhibition is succinylacetone, a metabolite found in tyrosinaemia $(28,29,30)$.

Tab. 3. Laboratory results of the familial study.

\begin{tabular}{|c|c|c|c|c|c|}
\hline Analytes & Brother & Sister & Daughter & $\begin{array}{l}\text { Grand- } \\
\text { daughter }\end{array}$ & $\begin{array}{l}\text { Reference } \\
\text { values }\end{array}$ \\
\hline \multicolumn{6}{|l|}{ Red blood cells } \\
\hline $\begin{array}{l}\text { Aminolaevulinate dehydratase } \\
\text { (5-aminolaevulinate, } \mu \mathrm{mol} / \mathrm{min} \cdot 1 \text { erythrocytes) } \\
\text { without additions } \\
+ \text { dithiothreitol } \\
+ \text { zinc chloride }\end{array}$ & $\begin{array}{l}29.0 \\
45.7 \\
51.3\end{array}$ & $\begin{array}{l}13.2 \\
16.6 \\
18.6\end{array}$ & $\begin{array}{l}12.6 \\
18.5 \\
20.5\end{array}$ & $\begin{array}{l}11.1 \\
16.8 \\
17.7\end{array}$ & $\begin{array}{l}20-60 \\
20-60 \\
20-60\end{array}$ \\
\hline $\begin{array}{l}\text { Porphobilinogen deaminase } \\
\text { (uroporphyrin, pmol/h } \cdot \mathrm{mg} \mathrm{Hb} \text { ) } \\
\text { Zinc protoporphyrin (nmöl/g Hb) }\end{array}$ & $\begin{array}{l}193 \\
2.7\end{array}$ & $\begin{array}{l}178 \\
4.0\end{array}$ & $\begin{array}{l}162 \\
3.5\end{array}$ & $\begin{array}{r}197 \\
4.0\end{array}$ & $\begin{array}{l}103-243 \\
<4.0\end{array}$ \\
\hline \multicolumn{6}{|l|}{ Plasma } \\
\hline $\begin{array}{l}\text { 5-Aminolaevulinate }(\mu \mathrm{mol} / \mathrm{l}) \\
\text { Porphobilinogen }(\mu \mathrm{mol} / 1)\end{array}$ & $\begin{array}{l}0.2 \\
0.0\end{array}$ & $\begin{array}{l}0.1 \\
0.0\end{array}$ & $\begin{array}{l}0.0 \\
0.0\end{array}$ & $\begin{array}{l}0.1 \\
0.0\end{array}$ & $\begin{array}{ll}0- & 0.6 \\
0- & 0.2\end{array}$ \\
\hline
\end{tabular}


Normal serum and urine amino acid patterns excluded tyrosinaemia, and therefore the presence of succinylacetone. The failure of dithiothreitol and zinc to restore aminolaevulinic acid dehydratase suggests a primary loss of activity of the enzyme, rather than an inhibition by lead or succinylacetone.

We therefore presumed that our patient suffers from a primary aminolaevulinic acid dehydratase deficiency.

During the investigation of certain members of the family, we found an intermediate aminolaevulinic acid dehydratase activity in a sister, in the daughter and in the grand-daughter of the patient, which indicates that this loss of activity is hereditary (tab. 3). Our results are in accordance with an autosomal recessive inheritance, as shown in the three other cases $(1,2)$, although our data do not exclude an X-linked inheritance.

Table 4 compares the results of biochemical investigations of porphyrin metabolism in the homozygous patients described in the literature $(1,2)$ with those obtained by us. All these patients showed a strong increase of 5-aminolaevulinate in the urine, together with a mild increase or a normal level of porphobilinogen in the urine. The plasma of our patient showed a dramatic increase of 5-aminolaevulinate and no detectable porphobilinogen. The remarkable discordance between 5 -aminolaevulinate and porphobilinogen points to the existence of ap enzymatic blockade at the aminolaevulinic acid dehydratase level. This enzymatic activity was not increased by reactivators.

In all patients, the urinary porphyrin profile showed a predominant coproporphyrin fraction, with a smaller increase of the uroporphyrin fraction. This type of profile can also be observed in heavy metal intoxication (1). The faecal porphyrin profile was less typical than that of urine; a coproporphyrin increase was found in two patients and a protoporphyrin increase in one patient. The erythrocyte porphyrins (protoporphyrin, zinc protophorphyrin, total porphyrins) were increased in all patients.

The porphobilinogen deaminase activity in erythrocytes was strongly increased in our patient, although no haemolytic anaemia was noticed. The three other

Tab. 4. Comparison of porphyrin metabolism in the homozygous aminolaevulinate dehydratase deficient patients. All results are expressed in \% of the upper reference values of each author.

\begin{tabular}{|c|c|c|c|c|}
\hline Analytes & Our patient & $\begin{array}{l}\text { Doss (1) } \\
\text { Patient } 1\end{array}$ & $\begin{array}{l}\text { Doss (1) } \\
\text { Patient } 2\end{array}$ & Thunell (2) \\
\hline \multicolumn{5}{|l|}{ Plasmatic precursors } \\
\hline $\begin{array}{l}\text { 5-Aminolaevulinate } \\
\text { Porphobilinogen }\end{array}$ & $\begin{array}{r}1155 \\
0\end{array}$ & & & $\cdot$ \\
\hline \multicolumn{5}{|l|}{ Plasmatic porphyrins } \\
\hline $\begin{array}{l}\text { Coproporphyrin } \\
\text { Protoporphyrin }\end{array}$ & & $\begin{array}{l}300 \\
127\end{array}$ & $\begin{array}{l}167 \\
327\end{array}$ & \\
\hline \multicolumn{5}{|l|}{ Urinary porphyrins and precursors } \\
\hline $\begin{array}{l}\text { 5-Aminolaevulinate } \\
\text { Porphobilinogen } \\
\text { Total porphyrins } \\
\text { Uroporphyrin fraction } \\
\text { Coproporphyrin fraction }\end{array}$ & $\begin{array}{r}794 \\
15 \\
\\
888 \\
2987 \\
\end{array}$ & $\begin{array}{r}2449 \\
238 \\
\\
361 \\
5380 \\
\end{array}$ & $\begin{array}{r}2373 \\
200 \\
224 \\
4698\end{array}$ & $\begin{array}{r}8150 \\
447 \\
7247\end{array}$ \\
\hline \multicolumn{5}{|l|}{ Faecal porphyrins } \\
\hline $\begin{array}{l}\text { Coproporphyrin } \\
\text { Protoporphyrin }\end{array}$ & $\begin{array}{l}285 \\
300\end{array}$ & $\begin{array}{l}\text { within ref } \\
\text { within ref }\end{array}$ & $\begin{array}{l}\text { ralues } \\
\text { ralues }\end{array}$ & $\begin{array}{r}284 \\
68 .\end{array}$ \\
\hline \multicolumn{5}{|l|}{ Blood porphyrins } \\
\hline $\begin{array}{l}\text { Zinc protoporphyrin } \\
\text { Protoporphyrin } \\
\text { Erytbrocyte total porphyrins }\end{array}$ & 408 & 3192 & 3164 & 663 \\
\hline \multicolumn{5}{|l|}{ Erythrocyte enzymes } \\
\hline $\begin{array}{l}\text { Aminolaevulinate dehydratase without additions } \\
\quad+\text { dithiothreitol } \\
\quad+\text { zinc ions } \\
\text { Porphobilinogen deaminase }\end{array}$ & $\begin{array}{r}1 \\
2 \\
1 \\
317\end{array}$ & $\begin{array}{r}0 \\
2 \\
108\end{array}$ & $\begin{array}{r}1 \\
2 \\
96\end{array}$ & $\begin{array}{l}0 \\
0 \\
0 \\
\text { within reference } \\
\text { values }\end{array}$ \\
\hline
\end{tabular}


patients, showed no increase of porphobilinogen deaminase activity. Does this represent an attempt of the cell to diminish the blockade of the enzymatic pathway by speeding up the transformation of porphobilinogen to uroporphyrinogen? On the other hand, could a myeloproliferative disorder provoke some modification of haem biosynthesis? An association of porphyria cutanea tarda with a chronic granulocytic leukaemia has been described before $(31,32)$.

The immunological characterization of the two patients of Doss showed a cross-reactive immunological material which corresponded to $20 \%$ and $33 \%$ of the control level (33). Therefore the molecular basis for the deficiency of aminolaevulinic acid dehydratase in these patients is a structurally modified enzyme (33). The methods used to determine the relative molecular mass (by Western blotting) and the isoelectric point (by chromatofocusing) of the mutants revealed no differences between the modified and normal enzymes (33). In the patient of Thunell, the immunoreactive enzyme protein in the child's erythrocytes was decreased to $28 \%$ of the normal control, suggesting the presence of positive cross reactive material (34). These results suggest that in these cases, the aminolaevulinic acid dehydratase deficiency is associated with the production of a catalytically abnormal enzyme protein $(33,34)$.

\section{References}

1. Doss, M., von Tiepermann, R., Schneider, J. \& Schmid, H. (1979) New type of hepatic porphyria with porphobilinogen synthase defect and intermittent acute manifestation. Klin. Wochenschr. 57, 1123-1127.

2. Thunell, S., Holmberg, L. \& Lundgren, J. (1987) Aminolevulinate dehydratase porphyria in infancy. A clinical and biochemical study. J. Clin. Chem. Clin. Biochem. 25, 5-14.

3. Doss, M., Schneider, J., Tiepermann, R. \& Brandt, A. (1982) New type of acute porphyria with porphobilinogen synthase (delta-aminolevulinate dehydratase) defect in the homozygous state. Clin. Biochem. 15, 52-55.

4. Mauzerall, D, \& Granick, S. (1956) The occurrence and determination of delta-aminolevulinic acid and porphobilinogen in urine. J. Biol. Chem. 219, 435-446.

5. Gajdos, A. \& Gajdos-Török; M. (1969) Porphyries et porphyrines, pp. 207-234, Masson, Paris.

6. Ford, R. E., Chin-Nan, Ou \& Ellefson, R. D. (1981) Liquid chromatographic analysis of urinary porphyrins. Clin. Chem. 27, 397-401.

7. de Verneuil, H. \& Nordmann, Y. (1979) Chromatographie liquide à haute performance (CLHP) Porphyrines et porphyries. Feuillets de biologie 20, 87-88.

8. Blumberg, W. E., Eisinger, J., Lamola, A. A. \& Zuckerman, D. M. (1977) The hematofluorometer. Clin. Chem. 23, $270-274$.

9. Berlin, A. \& Schaller, K. H. (1974) European standardized method for the determination of delta-aminolevulinic acid dehydratase in blood. Z. Klin. Chem. Klin. Biochem. 12, $389-390$.
Finally, the occurrence of the symptoms of porphyria for the first time at the age of 63 remains an enigma. Presumably the low activity of aminolaevulinic acid dehydratase had been present since birth, and to our knowledge this patient had never presented clinical symptoms of porphyria until the age of 63 .

\section{Conclusion}

A case of aminolaevulinic acid dehydratase hereditary deficiency is reported in a 63-year-old man affected by a motor polyneuropathy. The diagnosis was made:

1) from the increase of urinary and plasmatic aminolaevulinate, with non-detectable plasmatic porphobilinogen levels;

2) from the absence of heavy metal intoxication, tyrosinaemia, alcoholism, smoking, cirrhosis, renal insuficiency and diabetes mellitus;

3) from the failure to regenerate the activity of erythrocyte aminolaevulinic acid dehydratase. The familial study confirmed the hereditary autosomal recessive nature of this enzymatic deficiency.

\section{Acknowledgement}

We thank Ms. Ledoux for her efficient technical assistance in the investigation of porphyrin metabolism.

10. Granick, J. L., Sassa, S., Granick, S., Levere, R. D. \& Kappas, A. (1973) Studies in lead poisoning. II. Correlation between the ratio of activated to inactivated delta-aminolevulinic acid dehydratase of whole blood and blood lead levels. Biochem. Med. 8, 149-159.

11. Doss, M., Benkmann, H. G. \& Goedde, H. W. (1986) Deltaaminolevulinic acid dehydratase (porphobilinogen synthase) in two families with inherited enzyme deficiency. Clinical Genetics 30, 191-198.

12. Blanke, R. V. \& Decker, W. J. (1986) Analysis of toxic substances. In: Textbook of Clinical Chemistry (Tietz, N. W., ed.) pp. 1714-1715, W. B. Saunders Company, Philadelphia

13. Coyle, P. \& Hartley, T. (1981) Automated determination of mercury in urine and blood by the Magos reagent and coldvapor atomic absorption spectrometry. Anal. Chem. 53, $354-356$.

14. Kubasik, N. P. \& Volosin, M. T. (1973) A simplified determination of urinary cadmium, lead, and thallium, with use of carbon red atomization. Clin. Chem. 19, 954-958.

15. Valentin, H., Preusser, P. \& Schaller, K. H. (1976) Die Analyse von Aluminium im Serum und Urin zur Überwachung exponierter Personen. Int. Arch. Occup. Env. Health. $38,1-17$.

16. Bremer, H. J., Duren, M., Kamerling, J. P., Przymbel, H. \& Wadman, S. K. (1981) Disturbance of amino acid metabolism: clinical chemistry and diagnosis, pp. 458-465, Urban \& Schwarzenberg, Baltimore-Munich. 
17. Abdulla, M., Haeger-Aronsen, B. \& Svenson, S. (1976) Effect of ethanol and zinc on ALA-dehydratase activity in red blood cells. Enzyme 21, 248-252.

18. Kondo, M., Urata, G. \& Shimizu, Y. (1983) Decreased liver delta-aminolaevulinate dehydratase activity in porphyria cutanea tarda and in alcoholism. Clinical Science 65, 423428.

19. Allain, P., Froussard, E. \& Boyer, J. (1977) Relation entre le taux de zinc dans le sang et l'activité ALAD érythrocytaire chez l'homme. Clin. Chim. Acta 78, 183-189.

20. Salle, H. J. A. \& Zielhuis, R. L. (1977) Influence of smoking on ALA-D activity, hematocrit and lead in blood in adult urban woman. Int. Arch. Occup. Environm. Health 40, $111-115$

21. Vivoli, G., Vecchi, G., Ferrari, L. R. \& Borella, P. (1974) Comportamento dell'attivita 5 aminolevulinico dehydratasica in rapporto delle abitudini fumatori. Riv. Ital. Ig. $34,26-36$.

22. Buchet, J. P., Lauwerijs, R., Hassoun, A., Dratwa, M., Wens, R., Collart, F. \& Tielemans, C. (1987) Effect of aluminium on porphyrin metabolism in hemodialyzed patients. Nephron 46, 360-363.

23. Djordjevic, V. (1985) Delta-aminolevulinic acid dehydratase activity in erythrocytes of diabetic patients. Arch. Intern. Physiol. Biochim. 93, 285-290.

24. Abdulla, M., Svenson, S. \& Haeger-Aronsen, B. (1979) Antagonistic effects of zinc and aluminium on lead inhibition of delta-aminolevulinic acid dehydratase. Arch. Environ. Health $34,464-468$.

25. Lauwerijs, R. \& Buchet, J. P. (1973) Occupational exposure to mercury vapors and biological action. Arch. Environm. Health 27, 65-68.

26. Lauwerijs, R., Buchet, J. P. \& Roels, H. A. (1973) Comparative study of effect of inorganic lead and cadmium on blood delta-aminolevulinic acid dehydratase in man. Brit. J. Ind. Med. 30, 359-364.
27. Calissano, P., Càrtasegna, C. \& Bonsignore, D. (1965) Azione di alcuni metalli nell deidratasi erytrocitaria purificata da sangue umano. Lav. Umano 17, 493-497.

28. Sassa, S. \& Kappas, A. (1983) Hereditary tyrosinemia and the heme biosynthetic pathway. Profound inhibition of delta-aminolevulinic acid dehydratase activity by succinylacetone. J. Clin. Invest. 71, 625-634.

29. Lamon, J.-M., Frykholm, B. C. \& Tschudy, P. P. (1978) Tyrosinemia with aminolevulinic dehydratase deficiency. J. Pediatr. 91, 346.

30. Strife, F. C., Zuroweste, E. L. \& Emett, E. A. (1977) Tyrosinemia with acute intermittent porphyria aminolevulinic acid dehydratase deficiency related to elevated urinary aminólevulinic acid levels. J. Pediatr. 90, 400-404.

31. Kyle, R. A., Bowie, R. J. W. \& Brunsting, L. A. (1964) Porphyria cutanea tarda associated with refractory anemia (ineffective erythropoiesis) and thrombocythemia, Mayo Clinic Proceedings 39, 750-760.

32. Kyle, R. A. \& Dameshek, W. (1964) Porphyria cutanea tarda associated with chronic granulocytic leukemia treated with busulphan. Blood 23, 766-785.

33. de Verneuil, H., Doss, M., Brusco, N., Beaumont, C. \& Nordmann, Y. (1985) Hereditary hepatic prophyria with delta-aminolevulinic dehydrase deficiency: immunological characterization of the non-catalytic enzyme. Hum. Genet. 69, 174-177.

34. Fuyita, H., Sassa, S., Lundgren, J., Holmberg, L., Thunell, S. \& Kappas, A. (1987) Enzymatic defect in a child with hereditary hepatic porphyria due to homozygous deltaaminolevulinic acid dehydratase deficiency: immunochemical studies. Pediatrics 80, 880-885.
A. Hassoun
Service de Biochimie Médicale
Cliniques Universitaires St Luc
10, avenue Hippocrate
B-1200 Bruxelles 